\title{
EFFECT OF DIFFERENT ADDITIVES ON METALLIC LEAD RECOVERY FROM CRT FUNNEL GLASS USING THERMAL METHOD
}

Muna K. Abbass

mukeab2014@yahoo.com
Abdulkaliq F. Hmood,

Ibrahim K. Manhal abdulkaliq@yahoo.com ibrahimkarim321@yahoo.com University of Technology/ Dept. of Production Engineering and Metallurgy,

\section{ABSTRACT}

Cathode ray tube like as electronic waste is a green crisis due to its toxicity. Remove of the lead from CRT funnel glass can prevent it from release into the environmental and allow it reuse. There are several ways to separation lead from its CRT funnel glass and then recovered from it. In this research, CRT funnel glass was treated by high thermal reduction method with using different additives. These additives that used in this method are sodium carbonate $\left(\mathrm{Na}_{2} \mathrm{CO}_{3}\right)$ with $(20,25 \& 30)$ wt $\%$ used as a melting agent, sodium sulfide $\left(\mathrm{Na}_{2} \mathrm{~S}\right)$ with $(6$, $8 \& 10) w t \%$ used as a catalytic agent and carbon powder (C) with $(2.4,3.6 \& 4.8)$ wt $\%$ used as a reducing agent, at fixed temperature $\left(1100^{\circ} \mathrm{C}\right)$ and holding time $(120 \mathrm{~min})$. Taguchi technique for design of experiment (DOE) was applied to find the optimum process conditions of different additives for metallic lead recovery by high thermal reduction method. Experimental results presented that the maximum lead recovery was $97.36 \%$ when the optimum conditions were sodium carbonate (30\%), sodium sulfide (10\%), and carbon powder $(3.6 \%)$ at $1100^{\circ} \mathrm{C}$ and $120 \mathrm{~min}$.

Keywords: recovery of lead, CRT funnel glass waste, thermal method, carbon powder, recycling

$$
\begin{aligned}
& \text { تأثثر الاضافات المختلفة على استرجاع معدن الرصاص من زجاج انبوب الاشعة } \\
& \text { الكاثودُية ذو الزجاج المقمع بطريقة الاختزال الحراري }
\end{aligned}
$$

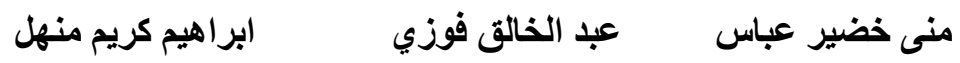

$$
\begin{aligned}
& \text { قسم هندسة الانتاج و المعادن - الجامعة التكنولوجية عيدية }
\end{aligned}
$$

إن أنبوب أنشعة الكاثودية ذو الزجاج المقمع (CRT funnel glass) له الكثير من الاهتمام اليوم لأنه أصبح مشكلة بيئية خطيرة

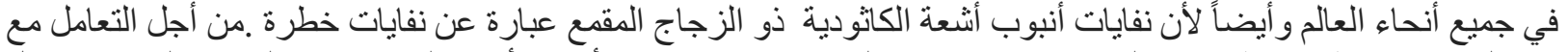

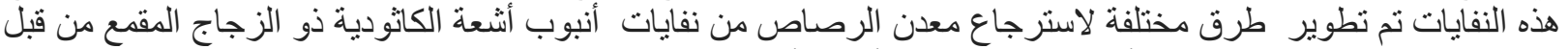

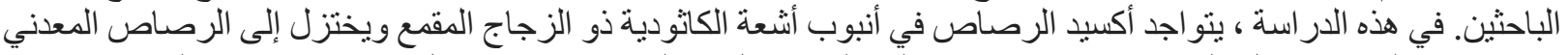

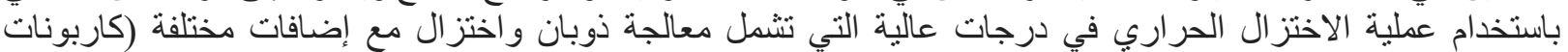

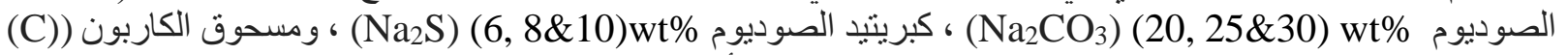

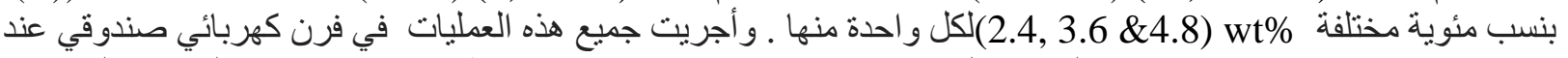

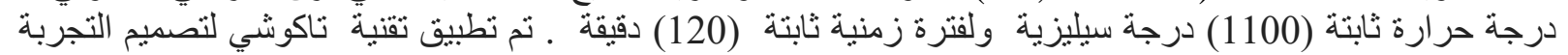

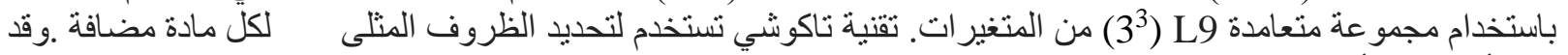

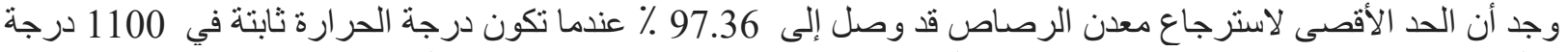

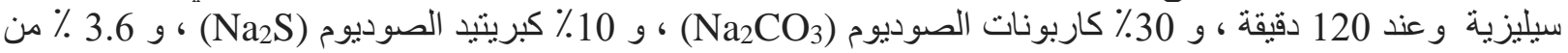




\section{INTRODUCTION}

Lead metal is an essential non-ferrous metal utilized in different productions such as in batteries, solders, dielectric materials, piezoelectric materials, and in glass. So that lead glass is a mixture of glass which lead replaced calcium in a characteristic potash glass. The major constituent of CRT glass which divided into three parts: 1) panel glass (65\%), a barium (Ba) strontium glass. 2) funnel glass (30\%), a Pb glass containing approximately (20 wt \%) lead (II) oxide. 3) neck glass (5\%), a very $\mathrm{Pb}-\mathrm{Pb}$ glass containing approximately $40 \mathrm{wt} \% \mathrm{PbO}$. Lead atoms comprised in lead glass are set hard in the glass arrangement. Lead recovery is imperfect under standard temperature and pressure circumstances. Lead in the Lead $(\mathrm{Pb})$ glass is powerfully attached which need to temperature than $1000{ }^{\circ} \mathrm{C}$ to extract lead from the silicone dioxide glass network [Chenglong Zhang et al.,2013]. The CRT waste funnel glass is disassembly of old TV wastes and PC review productions so because of that lead resources become the second major waste in the whole world. Technology of cathode ray tube for TV and computer was disused. There is no CRT waste manufacturing left to turn the CRT glass into new CRTs glass for new televisions and monitors. The CRT waste glass is able to be completed into anti-radiation glass and crafts, but the CRT waste glass requirement is little. Also cathode ray tube glass is able to utilize to production of foam glass, building thermal insulation material. As well, CRT waste funnel glass can used also as metal smelting flux and compound glass ceramic [ Biao Hu and Wenlong Hui, 2017]. CRT glass contains of three components as shown in Figure(1)[ Biao Hu and Wenlong Hui, 2017]. Cathode ray tube was once one of the close remarkable and mature technologies invented various long time in previous times. CRT is a showing instrument that produces electrons fired at phosphor to generate pictures. CRT was considered as simple and low cost to produce. Cathode ray tube was contains almost $85 \%$ glass which it was a piece of all PC and TV screens and accounted $55 \%$ of the whole weight of a TV and accounted 32\% of the PC screen [ Looking through glass ,2014]. The CRT was utilized widely in TV and PC reviews for more than 100 years. CRT was exchanged by the liquid crystal display, plasma display panel and digital light procession, When the display device technology innovation. When the CRT based places reached their unused, a huge CRT glass quantity can be produced and then becomes a significant environmental problem. The lead of high level in the waste CRT funnel glass becomes an ecological problem that because it contains hazardous characteristics [Zhitong Yao et al., 2016]. Removal of E-waste especially funnel glass waste has become to be a significant environmental problem through the world. The waste funnel glass is a lead rich silicate glass type that incorporates $(20-25) \mathrm{wt} \%$ of lead oxide $(\mathrm{PbO})$. The funnel glass has greater interest because of its high lead content that may contaminate the environment if it is not well disposal of it due to the funnel glass is an unsafe waste [ Poon, C.S.,2008; Herat S., 2008]. The funnel glass disposal is a most important problem in recycling of CRT waste glass which usually agreed that the best way to recycling of CRT glass is to utilize it to produce new CRTs. The international mass flow analysis presented that the CRT glass requirement is decreasing when CRTs exchanged by flat panel monitors. The CRT glass supply begin to surpass the requirement in 2015 , so that processing funnel glass to take away lead is a harmless method to evade the environment pollution [Wenyi Yuan et al. ,2015]. Recovery of different constituents found in E-waste like as metal, plastic, and also circuit board, is extra effective than production it from their raw materials. So because that cause, E-waste is a probable economical benefits resource [ Mesurt Ciftci and Bugra Cicek, 2017]. So that there are two exceptional ways for recycling leaded CRT glass which are: closed loop and open loop recycling. In closed loop recycling, disposal CRTs are utilized to supply a new CRT glass but this direction will be closed due to the fact the CRT supply will surpass the call for CRT production in 2015. In open loop recycling, CRT glass can be utilized in other programs which include flux in metallic smelting, foam glass, ceramic glaze and clay bricks [Siikamäki 
et al. ; Gregory et al.,2009 ]. Muna et al. in 2017 studied the temperature and time effect on recovery of lead from CRT funnel glass by pyro-vacuum reduction process. The parameters of used in the process are holding time $(1,2,3,4 \& 5 \mathrm{~h})$ and temperature $\left(700,800 \& 900{ }^{\circ} \mathrm{C}\right)$ with other fixed conditions such as pressure (10-1 $\mathrm{mm} \mathrm{Hg})$ and carbon adding amount $(9 \%)$. The maximum pure lead recovery has reached $99 \%$ at $900{ }^{\circ} \mathrm{C}$ and $5 \mathrm{~h}$ (optimum conditions). It was shown that the purity of recovered lead was $99 \%$ in pyro-vacuum process. The aim of this work is devoted to recovery the metallic lead from cathode ray tube (CRT) funnel glass using thermal method. The effect of different additives $\left(\mathrm{Na}_{2} \mathrm{CO}_{3}, \mathrm{Na}_{2} \mathrm{~S}\right.$ and carbon powder in various weight percentages for each one) on lead recovery are investigated with using Taguchi technique for DOE to find the optimum conditions for these different additives.

\section{EXPERIMENTAL WORK}

\section{Materials}

Cathode ray tube funnel glass (with inner and outer coatings removed) was prepared from waste old television. The CRT funnel glass block was breaking into tiny parts, crushed and grinding into fine powder by using jaw crusher (Retsch - BB200 rostfrei). The fine funnel glass powder was passed through 100 mesh $(149 \mu \mathrm{m})$ sieve by using auto sieve shaker type (Retsch, AS 300). The resulting fine funnel powder was dried out at $106^{\circ} \mathrm{C}$ for $24 \mathrm{hr}$. the funnel glass chemical composition was measured by using X-ray fluorescence spectroscopy (EDX7000; Shimadzu, Tokyo, Japan) as shown in Table(1). Other agents include sodium carbonate $\left(\mathrm{Na}_{2} \mathrm{CO}_{3}\right)$ used as analysis agent was passed through 100 mesh $(149 \mu \mathrm{m})$ sieve by using auto sieve shaker type (Retsch, AS 300) to wipe the particles agglomeration. Carbon powder (used as reducing agent), after crushing passed through 80 mesh $(177 \mu \mathrm{m})$ sieve by using auto sieve shaker type (Retsch, AS 300). Pure sodium sulfide $\left(\mathrm{Na}_{2} \mathrm{~S}\right)$ (used as a precipitating agent) was crushed by using mortar and then passed through 80 mesh $(177 \mu \mathrm{m})$ sieve by using auto sieve shaker type (Retsch, AS 300). Figure(2) shows the experimental work steps for preparation the CRT waste funnel glass powder.

\section{Lead recovery by thermal method}

The specific process route of generating metallic lead from the waste CRT funnel glass powder is shown in Figure (3). In the metallic lead recovery, $10 \mathrm{~g}$ of funnel glass waste fine powder (particle size $<149 \mu \mathrm{m})$ was mixed homogeneous with $(20,25 \& 30)$ wt $\%$ sodium carbonate powder (particle size $<149 \mu \mathrm{m}$, used as flux) and $(6,8 \& 10) \mathrm{wt} \%$ sodium sulfide (particle size $<177 \mu \mathrm{m}$, used as precipitating factor) and $(2.4,3.6 \& 4.8) \mathrm{wt} \%$ carbon powder (particle size $<177 \mu \mathrm{m}$, used as a reducing factor). So they become nine (9) experiments by using Taguchi design to achieve the optimum extraction conditions. Each mixture was put in a cylindrical crucible and after that put this cylindrical graphite crucible in a box type electric furnace at $1100{ }^{\circ} \mathrm{C}$ for $120 \mathrm{~min}$. After the nine experiments were done and then choose the best lead recovery percent which was $97.36 \%$ at $1100{ }^{\circ} \mathrm{C}$ and $120 \mathrm{~min}$ as shown in Table(2). After that holding the temperature and time and then alter the different additives materials percent as shown in Table(3), which includes the experiments results.

The lead recovery percent was obtained through this equation (1):

Example:

$$
\text { Lead recovery } \%=\frac{C 1-C 2}{c 1} \times 100 \%
$$

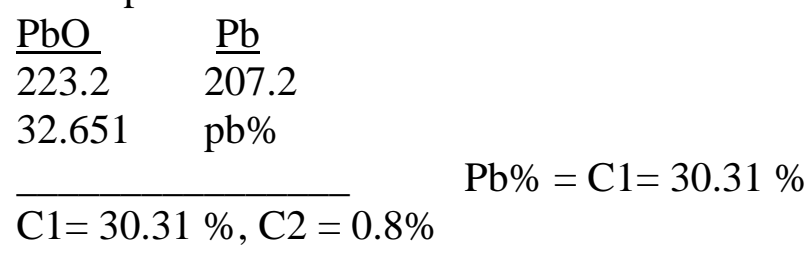


Lead recovery $\%=\frac{c 1-c 2}{C 1} \times 100 \%$

Lead recovery $\%=\frac{30,31-0.8}{30,31} \times 100 \%$

Lead recovery $\%=97.36 \%$

\section{RESULTS AND DISCUSSION}

\section{Results analysis and determining the optimum conditions}

After the whole experiments were accomplished, the results were listed in the Minitab program 16 database for numerical analysis as shown in Table(2) which shows Taguchi Orthogonal arrays L9 $\left(3^{3}\right)$ as well as their results, Means, and Signal to Noise ratio (S/N) for metallic lead recovery. The optimum conditions for the metallic lead recovery are shown in Table (3). Also, ranks for means of lead recovery factors and the levels are given in Table (4). Analysis of variance (ANOVA)

The efficient percent for every factor of metallic lead recovery percent was designed by using Minitab 16 program ANOVA as shown in Table(5).

\section{Effect of additives on recovery of lead}

Figure(4) indicates the effect of different additives on recovery of lead percent which explain the main effects plot for lead recovery. It was found that maximum lead recovery percent was $97.36 \%$ at $30 \% \mathrm{Na}_{2} \mathrm{CO}_{3}, 10 \% \mathrm{Na}_{2} \mathrm{~S}$, and $3.6 \%$ Carbon powder. The lead recovery percent increased when sodium carbonate amount increased because of sodium carbonate act as flux to improve the melting process and react with impurities to form slag. Also, when sodium supplied amount increased that because occur a reaction between sodium supplied and lead oxide that resulting to convert lead oxide to lead supplied with increase the sodium supplied amount so that lead recovery percent increased. Also, the lead recovery percent increased with increasing of carbon powder because of occurring reduction of lead supplied into metallic lead until reaching a certain amount of carbon powder then lead recovery percent begin to decrease with increasing of carbon powder amount. Figure(5) shows $\mathrm{S} / \mathrm{N}$ ratio for the metallic lead recovery factors.

\section{Effect of sodium sulfide addition}

The effect of sodium supplied percent on the recovery percent of metallic lead can be shown in Figure (4). The sodium supplied adding to the glass powder reduced glass powder viscosity through the melting process, that facilities the mixture of $\mathrm{Pb}^{2+}$ and $\mathrm{S}^{2-}$. When the added amount of sodium supplied was $6 \%$, the lead recovery percent was increased. With the sodium supplied amount increased from $8 \%$ to $10 \%$, the lead recovery percent was increased rapidly to $97.36 \%$ at $\% 30 \% \mathrm{Na} 2 \mathrm{CO} 3,10 \% \mathrm{Na} 2 \mathrm{~S}$ and $3.6 \mathrm{wt} \%$ carbon. Consistent with the exploratory instrument, the sodium supplied amount was added to produce lead supplied as shown in equation (1) [Yuan et al.,2013]. Other conditions (temperature and time) are fixed at $1100{ }^{\circ} \mathrm{C}$ for $120 \mathrm{~min}$.

$\mathrm{Na}_{2} \mathrm{~S}+\mathrm{PbO} \cdot \mathrm{MSiO}_{2}=\mathrm{PbS}+\mathrm{Na}_{2} \mathrm{O} \cdot \mathrm{mSiO}_{2}$

\section{Effect of sodium carbonate addition}

This effect of addition of sodium carbonate percent on the recovery percent of metallic lead can be shown in Figure (4). The lead recovery percent increased when the added sodium carbonate amount was increased and when the sodium carbonate amount reached $20 \%$, the lead recovery rate was increased. Then With increasing of sodium carbonate amount from 25 $\%$ to $30 \%$, the lead recovery rate increased to $97.36 \%$. The added sodium carbonate was 
changed to sodium silicate as shown in equation (2) \& (3) [Hu and Hui ,2018]. Other conditions (temperature and time) are fixed at $1100{ }^{\circ} \mathrm{C}$ for $120 \mathrm{~min}$.

$\mathrm{PbS}+\mathrm{Na}_{2} \mathrm{CO}_{3}+\mathrm{C}=\mathrm{Pb}+\mathrm{Na}_{2} \mathrm{~S}+\mathrm{CO}+\mathrm{CO}_{2}$

$\mathrm{PbS}+\mathrm{Na}_{2} \mathrm{CO}_{3}+\mathrm{CO}=\mathrm{Pb}+\mathrm{Na}_{2} \mathrm{~S}+2 \mathrm{CO}_{2}$

\section{Effect of carbon powder addition}

The effect of carbon powder on the recovery percent of metallic lead can be shown in Figure (4). Results showed that when the carbon powder percent was $2.4 \%$ the lead recovery percent was increased. Then Lead recovery percent increased to $97.36 \%$ when the added carbon powder amount was increased until lead recovery percent start to decreased when the added amount of carbon powder increased from $3.6 \%$ to $4.8 \%$. According to the equations (2) \& (3), the amount of carbon powder added was used by air oxygen that oxidizing by using high temperature process. Other conditions (temperature and time) are fixed at $1100{ }^{\circ} \mathrm{C}$ for 120 min. These results are confirmed by researchers Marcelo et al. in 2015.

\section{XRD and EDS Analysis}

Characterization of the recovered metallic lead was done by using X-ray diffraction (XRD). Figure (6) shows the recovered pure metallic lead at optimum conditions with maximum value of recovery percent $(97.15 \%)$ can be observed in XRD analysis. Table(6) shows the XRD identification of the pure metallic lead phase. The first three peaks with strongest intensities of pure metallic lead were $100 \%, 61 \%$ \& 53\% at Bragg angle $2 \theta$ (degree) 31.692, $30.496 \& 36.666$ respectively. Figures (7) and(8) show the SEM image and EDS spectrum respectively of the metallic lead after recovery at optimum conditions with maximum value of recovery percent $(97.36 \%)$ and with the highest purity of metallic lead (100\%).

\section{CONCLUSIONS}

1. High temperature thermal reduction process has successfully performed to give 97.36\% metallic lead recovery from CRT funnel glass.

2. According to Taguchi technique the optimum conditions of additives are $30 \%$ $\mathrm{Na}_{2} \mathrm{CO}_{3}, 10 \% \mathrm{Na}_{2} \mathrm{~S}$ and $3.6 \%$ carbon powder which gave the maximum lead recovery $97.36 \%$ with the highest purity of metallic lead (100\%).

3. The results have been found that the metallic lead recovery percent increased to maximum value $(97.36 \%)$ with increasing sodium carbonate percent from $20 \mathrm{wt} \%$ to $30 \mathrm{wt} \%$, sodium supplied percent from $6 \mathrm{wt} \%$ to $10 \mathrm{wt} \%$, and also when carbon powder percent increased from $2.4 \mathrm{wt} \%$ to $3.6 \mathrm{wt} \%$ at fixed temperature and time $\left(1100{ }^{\circ} \mathrm{C}\right.$ and $\left.120 \mathrm{~min}\right)$ respectively.

4. ANOVA analysis indicates that the contribution percent for carbon powder has the most effective parameter on metallic lead recovery percent $(43.3 \%)$ while the contribution percent for sodium carbonate $\left(\mathrm{Na}_{2} \mathrm{CO}_{3}\right)$ has less effect on the lead recovery percent $(11.7 \%)$. 


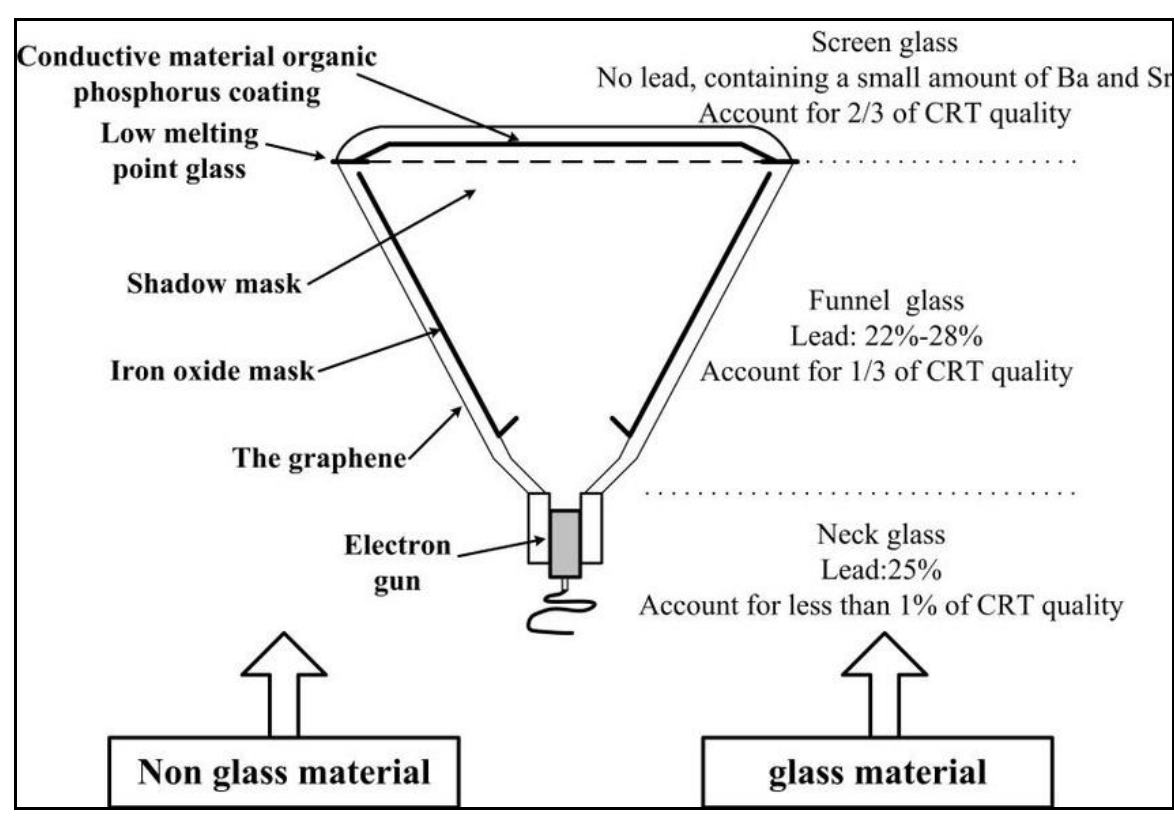

Fig.(1): CRT monitor structure [Biao Hu and Wenlong Hui, 2017]

Table(1): Chemical composition of CRT funnel glass waste by using XRF

\begin{tabular}{|c|c|}
\hline Oxide & $\begin{array}{c}\text { Weight percentage } \\
(\%)\end{array}$ \\
\hline $\mathrm{SiO}_{2}$ & 52.964 \\
\hline $\mathrm{PbO}$ & 32.651 \\
\hline $\mathrm{K}_{2} \mathrm{O}$ & 6.541 \\
\hline $\mathrm{Al}_{2} \mathrm{O}_{3}$ & 3.086 \\
\hline $\mathrm{CaO}$ & 2.999 \\
\hline $\mathrm{Fe}_{2} \mathrm{O}_{3}$ & 1.555 \\
\hline $\mathrm{Sb}_{2} \mathrm{O}_{3}$ & 0.078 \\
\hline $\mathrm{MnO}_{2}$ & 0.074 \\
\hline $\mathrm{TiO}_{2}$ & 0.073 \\
\hline $\mathrm{SrO}$ & 0.033 \\
\hline $\mathrm{CuO}$ & 0.021 \\
\hline $\mathrm{Rb}{ }_{2} \mathrm{O}$ & 0.013 \\
\hline $\mathrm{ZnO}$ & 0.011 \\
\hline
\end{tabular}



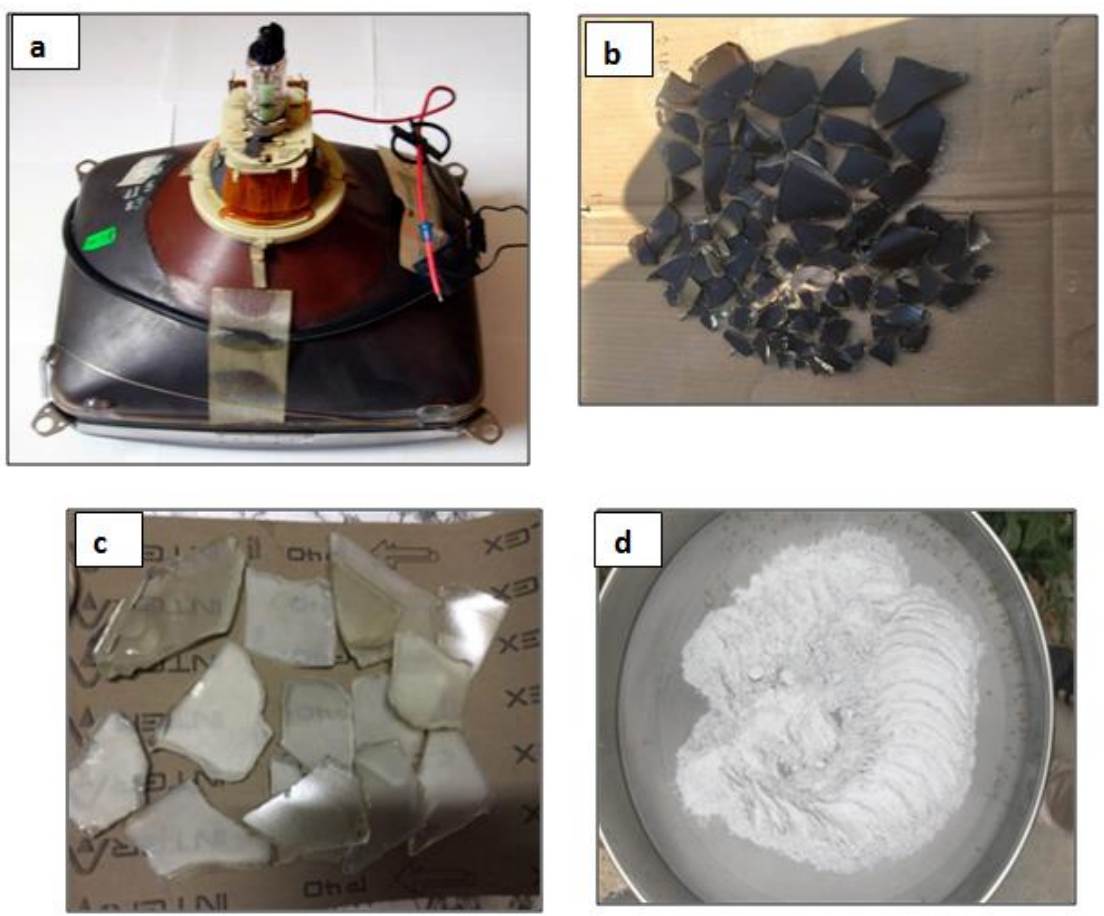

Fig. (2): Experimental work steps for preparation the waste CRT funnel glass powder

a) CRT TV scrap b) CRT funnel glass after break into pieces

c) CRT funnel glass after cleaning process d) Waste funnel glass powder

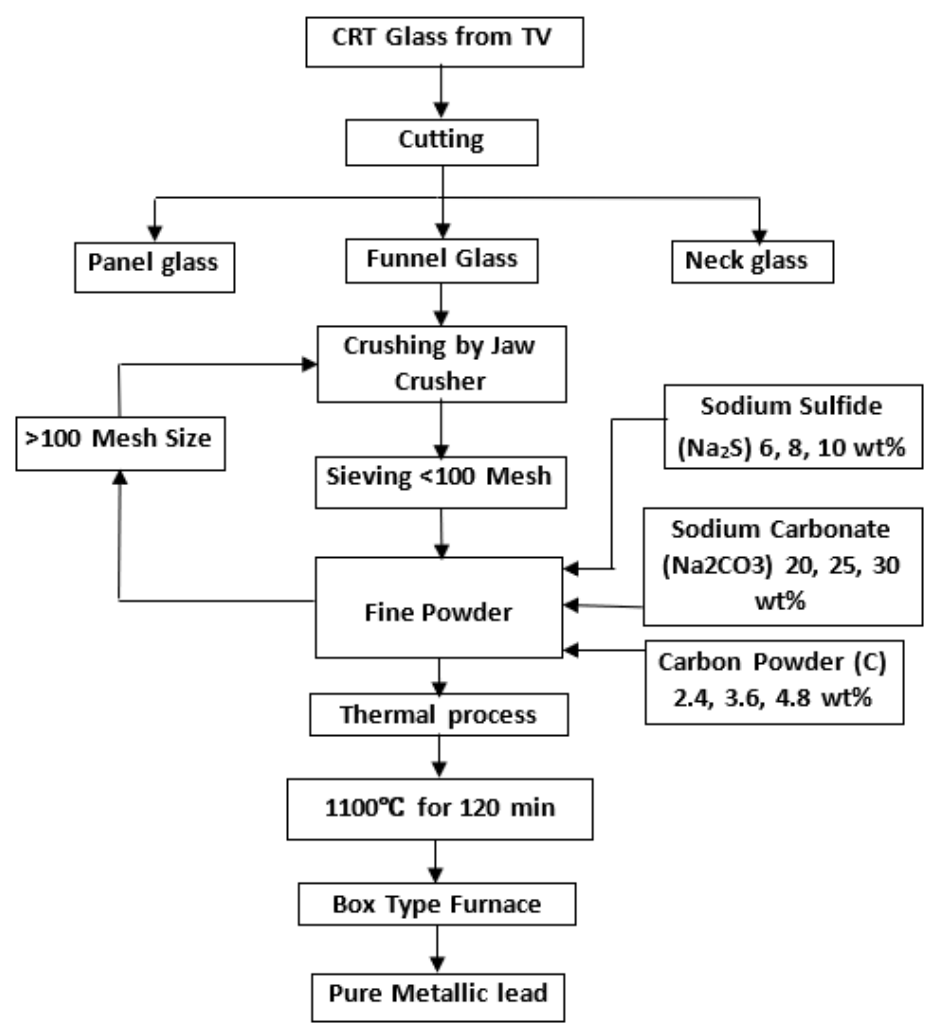

Fig.(3): Block diagram of the experimental work steps for lead recovery method 
Table (2): Experiment results after change of different additives (temperature $1100{ }^{\circ} \mathrm{C}$ and holding time $120 \mathrm{~min}$ are fixed).

\begin{tabular}{|c|c|c|c|c|c|c|c|c|c|}
\hline No. & $\begin{array}{c}\text { Sodium } \\
\text { carbonate } \\
\left(\mathrm{Na}_{2} \mathrm{CO}_{3}\right) \\
\text { wt } \%\end{array}$ & $\begin{array}{c}\text { Sodium } \\
\text { sulfide } \\
\left(\mathrm{Na}_{2} \mathrm{~S}\right) \\
\text { wt } \%\end{array}$ & $\begin{array}{l}\text { Carbon } \\
\text { powder } \\
\text { (C) wt \% }\end{array}$ & $\begin{array}{c}\text { Temperatu } \\
\text { re } \\
\left({ }^{\circ} \mathrm{C}\right)\end{array}$ & $\begin{array}{l}\text { Time } \\
\text { (min) }\end{array}$ & $\begin{array}{c}\text { Residue } \\
\text { Concentration } \\
\text { Wt } \%\end{array}$ & $\begin{array}{c}\text { Lead } \\
\text { Recovery } \\
\%\end{array}$ & SNRA & $\begin{array}{c}\text { Mean } \\
\%\end{array}$ \\
\hline 1 & 20 & 6 & 2.4 & $1100^{\circ} \mathrm{C}$ & 120 & 10.1 & 66.67 & 36.4777 & 66.6633 \\
\hline 2 & 20 & 8 & 3.6 & $1100^{\circ} \mathrm{C}$ & 120 & 3.2 & 89.44 & 39.0329 & 89.4633 \\
\hline 3 & 20 & 10 & 4.8 & $1100^{\circ} \mathrm{C}$ & 120 & 9 & 70.30 & 36.9436 & 70.3367 \\
\hline 4 & 25 & 6 & 3.6 & $1100^{\circ} \mathrm{C}$ & 120 & 7.3 & 75.91 & 37.6002 & 75.8600 \\
\hline 5 & 25 & 8 & 4.8 & $1100^{\circ} \mathrm{C}$ & 120 & 10 & 67.007 & 36.5613 & 67.3090 \\
\hline 6 & 25 & 10 & 2.4 & $1100^{\circ} \mathrm{C}$ & 120 & 1.045 & 96.55 & 39.6941 & 96.5400 \\
\hline 7 & 30 & 6 & 4.8 & $1100^{\circ} \mathrm{C}$ & 120 & 8.7 & 71.29 & 37.0601 & 71.2867 \\
\hline 8 & 30 & 8 & 2.4 & $1100^{\circ} \mathrm{C}$ & 120 & 4 & 86.80 & 38.7730 & 86.8267 \\
\hline 9 & 30 & 10 & 3.6 & $1100^{\circ} \mathrm{C}$ & 120 & 0.8 & 97.36 & 39.7795 & 97.4933 \\
\hline
\end{tabular}

Table (3): Optimum conditions value for the lead recovery percent

\begin{tabular}{|l|l|l|}
\hline Controlled factor & Value & Level \\
\hline Sodium carbonate $\left(\mathrm{Na}_{2} \mathrm{CO}_{3}\right)$ & 30 & 3 \\
\hline Sodium sulfide $\left(\mathrm{Na}_{2} \mathrm{~S}\right)$ & 10 & 3 \\
\hline Carbon powder $(\mathrm{C})$ & 3.6 & 2 \\
\hline
\end{tabular}

Table (4): Ranks for Means and level of lead recovery factors

\begin{tabular}{|c|c|c|c|}
\hline Level & Sodium carbonate & Sodium sulfide & Carbon powder \\
\hline 1 & 37.48 & 37.05 & 38.31 \\
\hline 2 & 37.95 & 38.12 & 38.80 \\
\hline 3 & 38.54 & 38.81 & 36.86 \\
\hline Delta $(\Delta)$ & 1.05 & 1.76 & 1.95 \\
\hline Rank & 3 & 2 & 1 \\
\hline
\end{tabular}

Table(5): Analysis of variance (ANOVA) for lead recovery

\begin{tabular}{|c|c|c|c|c|}
\hline Source of variance & $\begin{array}{c}\text { Degree of } \\
\text { freedom } \\
\text { (DOFc) }\end{array}$ & $\begin{array}{c}\text { Sum of Square } \\
\text { (SS) }\end{array}$ & Variance & $\begin{array}{c}\text { P contribution } \\
\mathbf{\%}\end{array}$ \\
\hline Sodium Carbonate & 2 & 1.6697 & 0.83485 & 11.720 \\
\hline Sodium Sulfide & 2 & 4.7220 & 2.361 & 33.145 \\
\hline Carbon Powder & 2 & 6.1700 & 3.085 & 43.309 \\
\hline Error & 2 & 1.6847 & & 11.825 \\
\hline Total & 8 & 14.2464 & & 100 \\
\hline
\end{tabular}




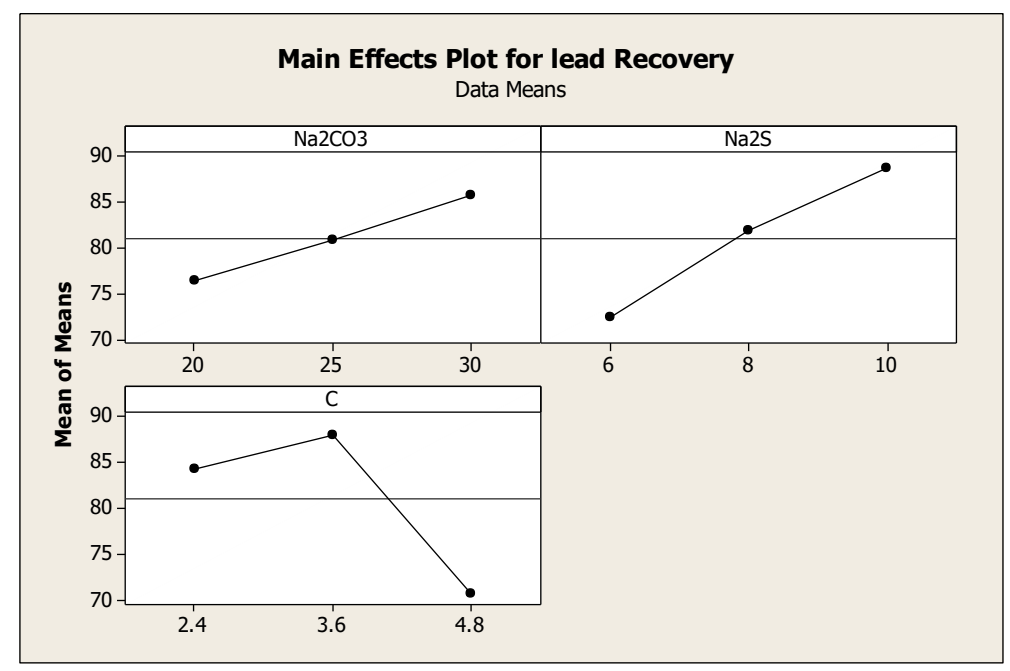

Fig.(4): Effect of different additives on the metallic lead recovery percent

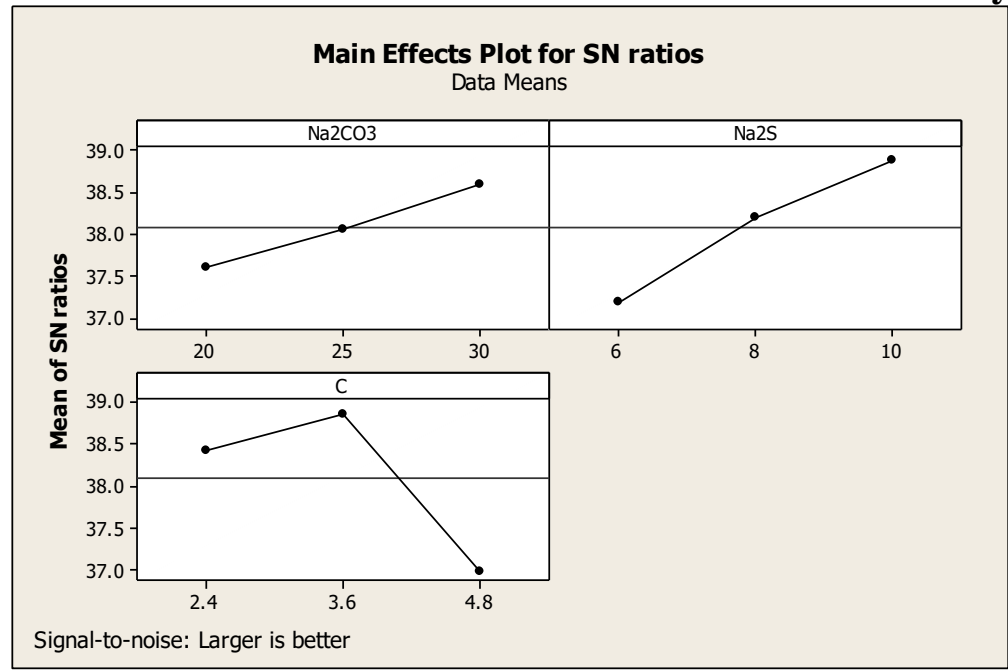

Fig. (5): $\mathrm{S} / \mathrm{N}$ ratio for the metallic lead recovery factors

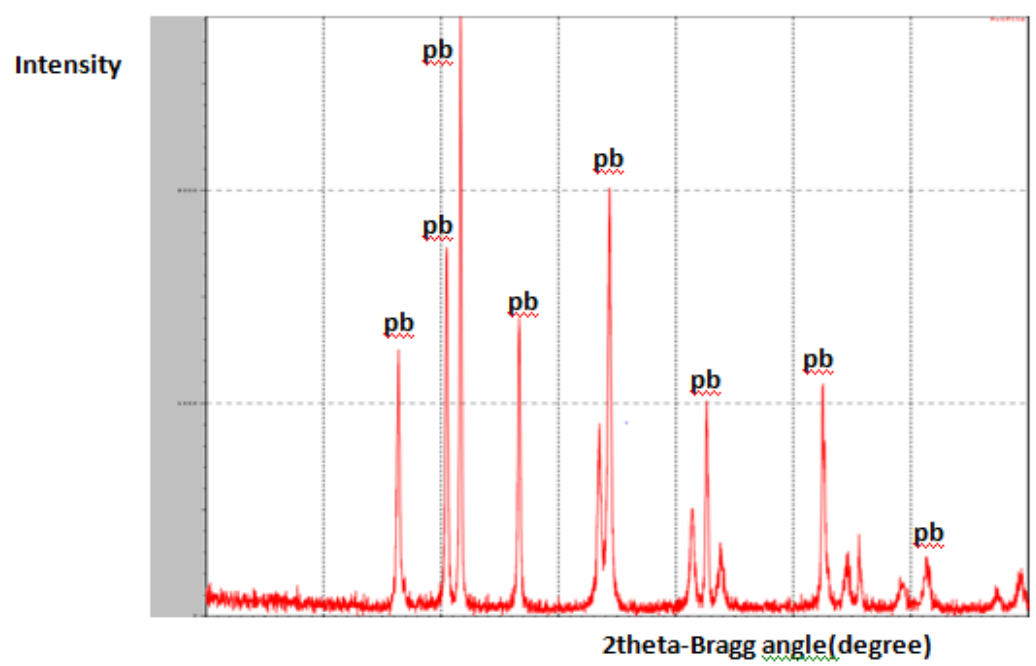

Fig.(6): XRD pattern of the recovered metallic lead 
Table (6): XRD data for the recovered metallic lead

\begin{tabular}{|c|c|c|c|c|}
\hline $\begin{array}{c}2 \theta \text { deg. } \\
\text { Standard }\end{array}$ & $\begin{array}{r}2 \theta \text { deg. } \\
\text { Measured }\end{array}$ & $\begin{array}{c}\text { d Measured } \\
\left(\mathrm{A}^{\circ}\right)\end{array}$ & $\begin{array}{c}d \text { Standard } \\
\left(\mathrm{A}^{\circ}\right)\end{array}$ & $\mathbf{I} \mathbf{I}_{\mathbf{o}}$ \\
\hline 31.692 & 31.692 & 2.820 & 2.820 & 100 \\
\hline 44.337 & 44.337 & 2.041 & - & 71 \\
\hline 30.496 & 30.496 & 2.928 & 2.957 & 61 \\
\hline 26.391 & 26.391 & 3.374 & 3.310 & 40 \\
\hline 36.666 & 36.666 & 2.448 & 2.50 & 53 \\
\hline 43.461 & 43.461 & 2.080 & 2.081 & 27 \\
\hline 52.616 & 52.616 & 1.738 & 1.740 & 41 \\
\hline 62.513 & 62.513 & 1.484 & 1.485 & 47 \\
\hline
\end{tabular}

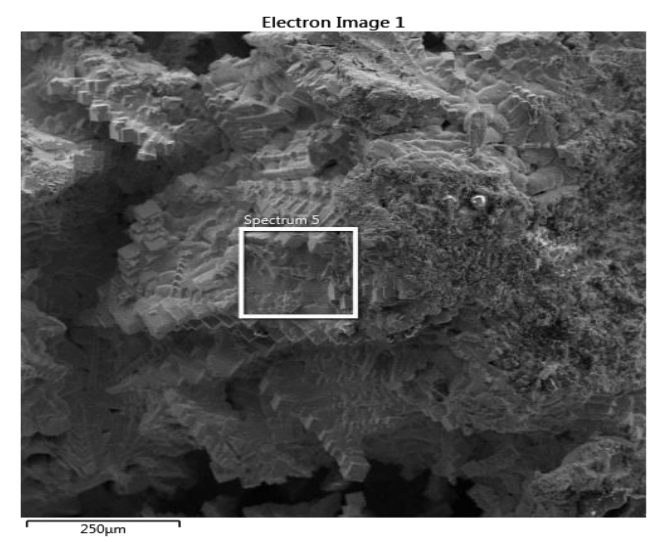

Fig. (7): SEM image of metallic lead after recovery

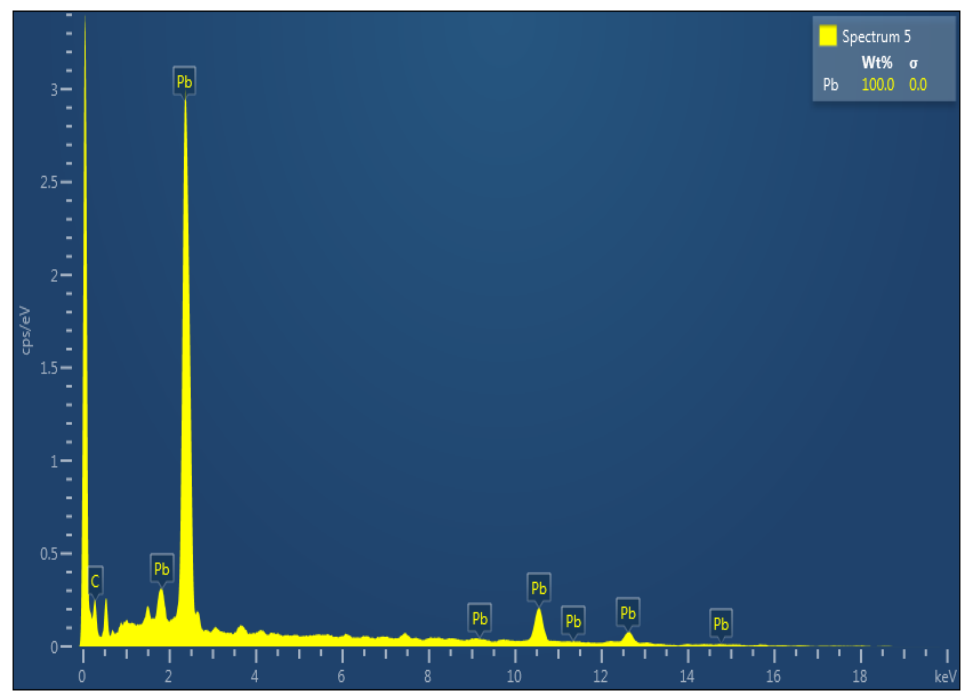

Fig. (8): EDS spectrum of metallic lead after recovery

\section{REFERENCES}

Biao $\mathrm{Hu}$ and Wenlong Hui, "Lead recovery from waste CRT funnel glass by high temperature", Journal of Hazardous Materials, (343) 220-226, 2017. 
Chenglong Zhang, Jingwei Wang, Jianfeng Bai, Jie Guan, Wenjie $\mathrm{Wu}$ and Cuixiang Guo, "Recovering lead from cathode ray tube funnel glass by mechano-chemical extraction in alkaline solution", Waste Management \& Research,31(7) 759-763, 2013.

Gregory J.R., Nadeau M.C., Kirchain R.E ,"Evaluating the economic viability of a material recovery system: the case of cathode ray tube glass", Environmental Science and Technology, 43, (2009):9245-9251.

$\mathrm{Hu}$ B. and Hui W., "Lead recovery from waste funnel glass by high temperature melting process", J. Hazardous Materials, 343, (2018):220-226.

Herat, S.,"Recycling of cathode ray tubes (CRTs) in electronic waste", Clean, 36, (2008):1924.

Looking through glass, CRT Glass Recycling in INDIA, Toxics Link, 2014.

Mesurt Ciftci and Bugra Cicek, "E-waste: A Review of CRT (Cathode Ray Tube) Recycling”, Journal of Material Science, 5, (2017):1-2.

Muna K. Abbass, Abdulkaliq F. Hmood, Salam Z. Abbas, "Effect of Temperature and Time on Lead Recovery from Waste Cathode Ray Tube Funnel Glass by Pyrovacuum Reduction Technique", American International Journal of Research in Science, Technology, Engineering \& Mathematics, 20, (1), (2017): 50-54.

Marcelo H., Oliveira E.D. , Richter G., "Thermal processes for lead removal from the funnel glass of CRT monitors", Metallurgy and Materials, 68, no.(3), (2015).

Poon, C.S.,"Managegment of CRT glass from discarded computer monitors and tv sets", Waste Manag., 28, (2008):1499.

Siikamäki R., Döring E, Manninen J.,"Closed loop and open loop applications for end of life cathode ray tube glass reccycling", Vienna Austria: going green care innovation.

Wenyi Yuan, Wen Meng, Jinhui Li, Chenglong Zhang, Qingbin Song, Jianfeng Bai, Jingwei Wang and Yingshun Li, "Lead recovery from scrap cathode ray tube funnel glass by hydrothermal sulphidisation", Waste Management \& Research, 33(10) 930-936, 2015.

Yuan W., Li j., Zhang Q. , Saito F., Yang B., "A novel process utilizing mechanochemical sulfidization to remove lead from cathode ray tube funnel glass", J. Air Waste Management Association, 63, no. (4), (2013):418-423.

Zhitong Yao, Zhengmiao Xie, Junhong Tang, "A typical e-waste cathode ray tube glass: alkaline leaching in the sulfur containing medium”, (31)880-886, 2016. 